\title{
First Report of Diplodia pinea [(Desmaz.) J. Kick $x$ fill] on Blue pine (Pinus wallichiana Jackson) from Asia
}

\author{
Shubana Bhat ${ }^{1 *}$, Muzafer A. Beig ${ }^{1}$, G. H. Dar ${ }^{1}$, Shanaz Yousuf ${ }^{1}$, \\ Farahanaz Rasool ${ }^{1}$ and Vikas Gupta ${ }^{2}$ \\ ${ }^{1}$ Division of Plant Pathology, SKUAST-Kashmir, India \\ ${ }^{2}$ Krishi Vigyan Kendra-Leh, SKUAST-Kashmir, India \\ *Corresponding author
}

\section{A B S T R A C T}

\begin{tabular}{|l|}
\hline K e y w o r d s \\
$\begin{array}{l}\text { Blue pine, Diplodia } \\
\text { pinea, Morphology, } \\
\text { Pathogenicity, } \\
\text { Symptomatology }\end{array}$ \\
\hline Article Info \\
\hline $\begin{array}{l}\text { Accepted: } \\
\text { 22 May } 2018 \\
\text { Available Online: } \\
\text { 10 June } 2018\end{array}$ \\
\hline
\end{tabular}

\section{Introduction}

Blue pine (Pinus wallichiana Jackson), a 30$50 \mathrm{~m}$ high large pyramidal temperate tree, belongs to the family Coniferaceae and grows at an altitude of $1200-4300 \mathrm{~m}$ amsl. The tree is native to Himalayan, Karakorum and HinduKush mountains which spread from eastern Afghanistan across northern India to Yunnan in south-west China. Like other conifers, blue pine is prone to a number of diseases which pose serious threat to its regeneration. The most damaging diseases of blue pine are root rot (Phytophthora cinnamomi), damping-off (incited by a number of species from genus Pythium, Phytophthora and Rhizoctonia),
Annosum root disease (Heterobasidium annosum), pitch canker (Fusarium subglutinans), Fusarium rust (Cronartium quercum f. sp. fusiforme), shoot blight (Diplodia pinea) and needle blights (Douce et al., 2002). The needle blight in pine plants are caused by several pathogens such as Diplodia pinea syn. Sphaeropsis sapinea (Diplodia tip blight), Scirrhia pini (red band needle blight), Lophodermium seditiosum and L. pinastri (Lophodermium needle cast), Ploioderma spp. (Ploioderma needle cast), Cercospora pinidensiflora (Cercospora needle blight), Meloderma desmazierii (needle blight), Phoma eupyrene (Phoma blight), etc. (Reddy and Pandey, 1973; Gadgil, 1984; Ivory, 1994; 
Brown et al., 2003; Jerry and Richard, 2008; Ahanger et al., 2011). Very scanty work has been done on pine diseases in India especially with respect to their status, symptomatology and management (Reddy and Pandey, 1973; Sujan Singh et al., 2007; Ahanger et al., 2011). Cercospora needle blight disease (Cercospora pini-densiflora) in Pinus radiata was reported from Madhya Pradesh and in Pinus oocarpa and $P$. kesiya nurseries and young plantations from Uttar Pradesh and Uttaranchal by Reddy and Pandey (1973) while as Sujan Singh et al., (2007) reported Cercoseptoria needle blight (Cercoseptoria pini) in $P$. roxberghii nurseries from Dehra Dun, Uttaranchal. Ahanger et al., (2011) reported Lophodermium needle blight caused by Lophodermium sp. from Asia. The needle blight diseases in pines go unnoticed as they affect plantation in scattered manner but adversely affect nurseries, so urgent need was felt to explore the causal agents of needle blights in pine in Kashmir Himalayas so that effective management strategies could be developed. In present communication, we report the needle blight in Blue pine caused by Diplodia pinea in pines of Kashmir Himalayas.

\section{Materials and Methods}

The diseased pine needle samples with typical blight symptoms were collected from various forest locations in Kashmir valley viz., Kralsangri (Srinagar), Gagribal (Srinagar), Tangmarg (Baramulla) and Forest Nursery, SKUAST-Kashmir, Shalimar (Srinagar). The symptomatological studies were conducted on two year old saplings as well as on 10 year old plantations of blue pine, selected randomly in the Forest Nursery, SKUAST-Kashmir, Shalimar. The selected plants were tagged and observations recorded fortnightly right from the initiation of the disease i.e. from $1^{\text {st }}$ fortnight of February to $2^{\text {nd }}$ fortnight of June during the years 2011 and 2012 with respect to the size, shape and colour of lesions and formation of fruiting structures. The samples were brought to the laboratory for isolation and further studies. The pathogen was isolated from the needles of blue pine seedlings exhibiting typical disease needle blight symptoms. For this, the naturally infected needles were brought to the laboratory and examined under stereoscopic microscope for the associated fungi. The needles were cut into small pieces, immersed for 1 minute in $70 \%$ ethanol, surface sterilized for 5 minutes in sodium hypochlorite (4\% active chlorine) and then transferred to sterile filter paper to dry. These tissue pieces were placed in petriplates containing oat meal agar (OMA) and incubated for 4 weeks at $25+1{ }^{\circ} \mathrm{C}$ (Phillips et $a l ., 2005)$. The hyphal tips growing from these tissues were removed and transferred to potato dextrose agar (PDA) slants. The pure culture isolates were also obtained by single conidial culture, transferred to PDA slants/plates under aseptic conditions and incubated at $24 \pm 1{ }^{\circ} \mathrm{C}$. Monoconidial isolates were maintained at 5$10^{\circ} \mathrm{C}$ on PDA slants (Palmer et al., 1987). Mycelial growth, colony shape, size and colour exhibited by monoconidial culture of the fungus were recorded. The cultures were periodically sub-cultured on freshly prepared PDA slants after every 30 days. The stock cultures in PDA slants were stored at $4^{\circ} \mathrm{C}$ in a refrigerator.

The morphological characters of the fungus were studied both on host as well as in culture (in laboratory). Infected fallen and attached needles with initials of fruiting structures were collected and kept in humid chamber at room temperature $\left(25 \pm 1^{\circ} \mathrm{C}\right)$ and observation with respect to fungal fruitification noted after 3 days. The swollen fruiting structures on needles were observed under stereoscopic microscope. Various morphological characters were examined under microscope at $40 \mathrm{X}$ by making semi-permanent slides of fruiting structures of the pathogen. The fruiting 
structure (pycnidia and conidia) were studied with respect to their size, shape, colour, septation and ornamentation to find out the imperfect state of the fungus and formation of perfect state (if any). Colony characters were studied with respect to shape, size, colour, septation, branching of mycelium and fructification, if any, by making semipermanent slides from seven day old culture. The photographs were taken using digital still camera model No. DSC- WX150.The pathogen was identified on the basis of disease symptoms on host, and morphological characters of mycelium, conidia and conidiophores, produced on host as well in culture, compared with the standard descriptions (Alves et al., 2006; Lazzizera et al., 2008; Phillips et al., 2005; Phillips et al., 2013). The identification of the isolated pathogen was also sent to ITCC, New Delhi, India for confirmation.

The pathogenicity of isolated fungus was established by confirming the Koch's postulates on two year old blue pine saplings grown in polybags under controlled conditions and on the terminal shoots of 5-10 years old pine plants in field. For nursery studies, apparently healthy saplings of blue pine were first kept under continuous observation for two months to rule out any latent infection. The saplings were then sprayed with sterilized distilled water, prior to inoculation. One set of plants was given injury with the help of sterilized syringe and another set kept uninjured.

Inoculations were made by spraying sporulating mycelial macerates taken from 3week old culture of the isolated fungus (Rees and Webber, 1987). The spore suspension containing $2 \times 10^{3}$ spores $/ \mathrm{ml}$ was adjusted with the help of a haemocytometer. The controlled saplings were sprayed with sterile distilled water alone. Three replications were maintained for each set. The inoculated plants alongwith control were incubated in a moist chamber at ambient temperature for 15 days and then shifted to polyhouse having a temperature of $25 \pm 1^{\circ} \mathrm{C}$ and relative humidity > $98 \%$. Sapling health was regularly monitored for 60 day period for any typical needle blight symptoms. The diseased tissues were used for reisolation of the fungus and compared with the mother isolates. Pathogenicity was also conducted on 5-10 year old pine plants. In this case, approximately $2 \mathrm{~cm}$ dia. stem of each terminal shoot of selected plants was girdled. A sterile toothpick colonized by the pathogen was inserted into a slit made in the stem approximately $30 \mathrm{~cm}$ from the terminal bud and then wrapped with parafilm (Palmer et al., 1987). The control plants were sprayed with sterile distilled water alone. The inoculated plants were regularly monitored for disease symptom development. Reisolations were made from each plant to verify the presence of fungus.

\section{Results and Discussion}

The needle blight symptoms on blue pine saplings and plantations initiated in the $2^{\text {nd }}$ fortnight of February as minute chlorotic spots on current year needles. The chlorotic spots measured 1.0 to $5.0 \mathrm{~mm}$ in size (avg: $2.5 \mathrm{~mm}$ ) in $1^{\text {st }}$ fortnight of March. The lesions became light yellow, increased longitudinally and measured 4.5-9.0 $\mathrm{mm}$ in size (avg: $5.0 \mathrm{~mm}$ ) in $2^{\text {nd }}$ fortnight of March. The lesions then became brown with a yellow halo, coalesced resulting in necrotic patches and increased up to $8.5-20 \mathrm{~mm}$ in size (avg: $14.0 \mathrm{~mm}$ ) in the $1^{\text {st }}$ fortnight of April. The curling of ash grey needles was observed in the $1^{\text {st }}$ fortnight of May resulting in the initiation of pycnidia on necrotic patches/blightened needles. In $2^{\text {nd }}$ fortnight of May, mature pycnidia with spores were observed on necrotic patches/blightened needles. In $1^{\text {st }}$ fortnight of June, premature defoliation resulted in the death of the entire blightened needles. 
The pathogen was successfully isolated from the infected needles of blue pine bearing fructification. The pycnidia observed on both the infected and fallen pine needles were usually unilocular, globose, separate or aggregated, immersed in host tissue, black in colour and measured $250-500 \mu \mathrm{m}$ in diameter (Avg: $402.50 \mu \mathrm{m}$ ) [Plate A-D]. The conidiophores were absent and conidia were borne on conidiogenous cells. The conidiogenous cells were cylindrical, discrete, indeterminate, holoblastic producing single apical conidium, hyaline and measured 10.0$12.5 \times$ 2.5-5.0 $\mu \mathrm{m}$ in size (avg: $11.50 \times 4.12$ $\mu \mathrm{m})$. The conidia were clavate or ellipsoidal, straight to slightly curved with a truncate base, apex broadly rounded and aseptate, occasionally developed single transverse septa, hyaline when immature, however became brown prior to discharge and measured 17.5-42.5 x 10.0-12.5 $\mu \mathrm{m}$ in size (avg. $34.12 \times 11.60 \mu \mathrm{m}$ ).

The culture of the isolated fungus was purified and raised on PDA. The fungus grew fast on PDA at $25^{\circ} \mathrm{C}$ and covered $44.5 \mathrm{~mm}$ surface area of $90 \mathrm{~mm}$ Petri-dish within 3 days. The purified culture on PDA produced colony which was floccose, cottony, raised in the centre, slightly white in colour after 3 days, then turned light greyish green after 5 days and finally became dark grey to black after 7 days of incubation. Stereo-microscopic examinations revealed the aggregation of mycelial strands after 7 days which required alternate light/dark periods of 12 hours to form pycnidial initials. After 21 days of incubations, mature black pycnidia were produced in culture which were more concentrated at centre and scattered throughout the colony.

In culture, the mycelium was branched, thick walled, rough, hyaline to olivaceous brown, septate and measured 2.5-5.0 $\mu \mathrm{m}$ in width (avg: $3.37 \mu \mathrm{m}$ ). Pycnidia were partially embedded in culture, became erumpent at maturity, scattered, unilocular, black and measured 300-550 $\mu \mathrm{m}$ in diameter (avg.: $428.75 \mu \mathrm{m}$ ) [Plate E-H]. The conidiophores were absent.

Conidiogenous cells and conidia were similar to those observed on host, except measuring a little larger (conidiogenous cells: 12.5-15.0 x 5.0-7.5 $\mu \mathrm{m}$; avg: 13.50 x $5.87 \mu \mathrm{m}$; conidia: 20.0-45.0 x 10.0-15.0 $\mu \mathrm{m}$, avg. $39.75 \times 12.20$ $\mu \mathrm{m})$. Conidia developed single septa after 21 days incubation. No perfect state fructifications were observed either on host or in culture.

The pathogenicity of isolated pathogen was successfully established on two year old blue pine saplings under greenhouse conditions and on terminal shoots of 5-10 year old blue pine trees under field conditions. The study revealed that the initial chlorotic symptoms, incited by D.pinea, appeared on $5^{\text {th }}$ and $7^{\text {th }}$ day of incubation, respectively on injured and uninjured blue pine saplings whereas initial symptom expresssion, respectively on injured and uninjured shoots was observed on $14^{\text {th }}$ and $16^{\text {th }}$ day of inoculation.

On the basis of culturo-morphological characteristics, pathogenicity and comparison with the authentic descriptions (Alves et al., 2006; Lazzizera et al., 2008; Phillips et al., 2005; Phillips et al., 2013;), the pathogen was identified as Diplodia pinea (Desmaz.) J. Kickx fil. The identity of the pathogens was also confirmed from ITCC, New Delhi under accession no. 9337.14.

First described in 1909 as a pathogen in South African pine plantations, (Nichols and Ostry, 1990; Palmer, 1991; Palmer et al., 1985; USDA Forestry Service, 2005), Diplodia pinea has also been reported on a myriad of pine species throughout the world (Punithalingam and waterson, 1970). 


\section{Morphological characters of Diplodia pinea a) on host}

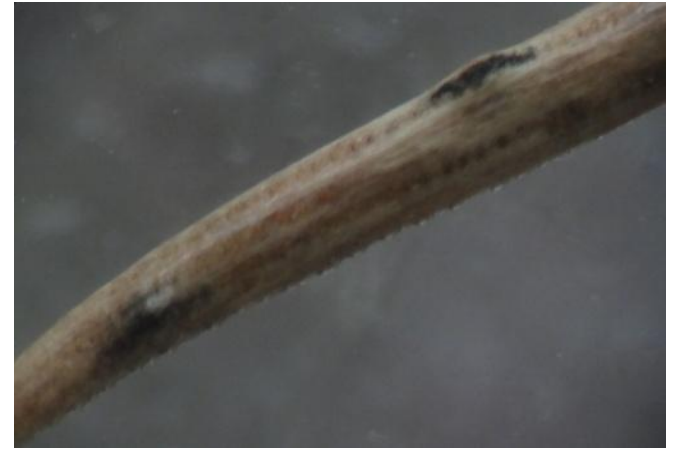

(a) Semi-immersed pycnidia (400 X)

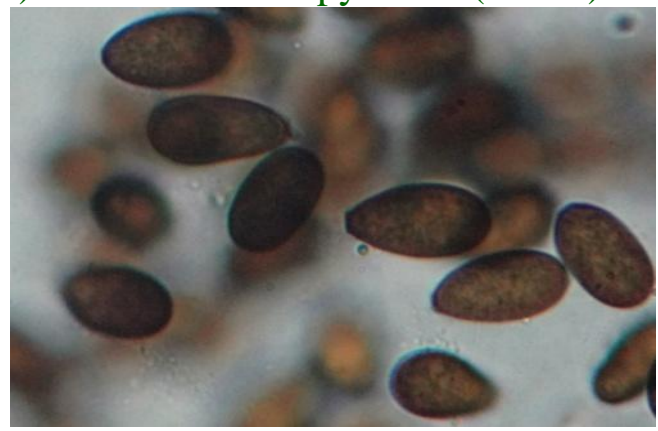

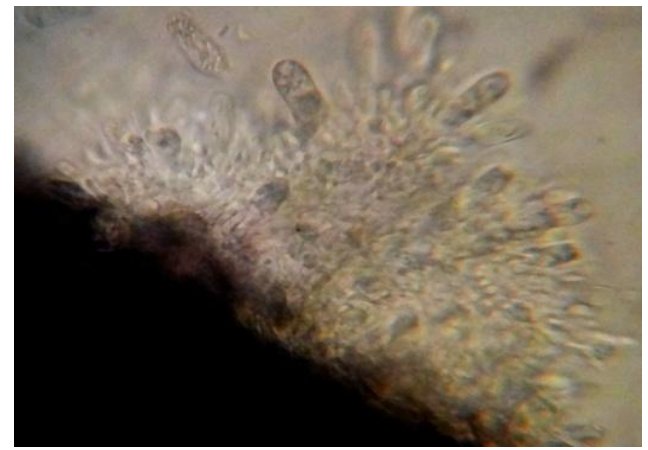

(b) conidia on conidiogenous cells 400X

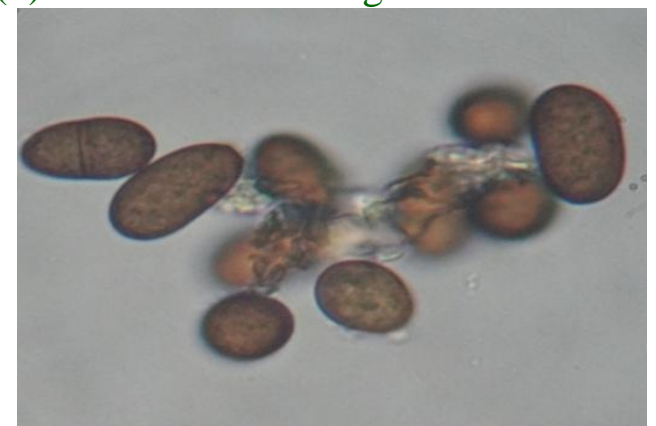

(C) Mature conidia (400X)

(d) Conidia with truncate base (400X withoptical Zoom 3.6)

\section{Morphological characters of Diplodia pinea in culture}

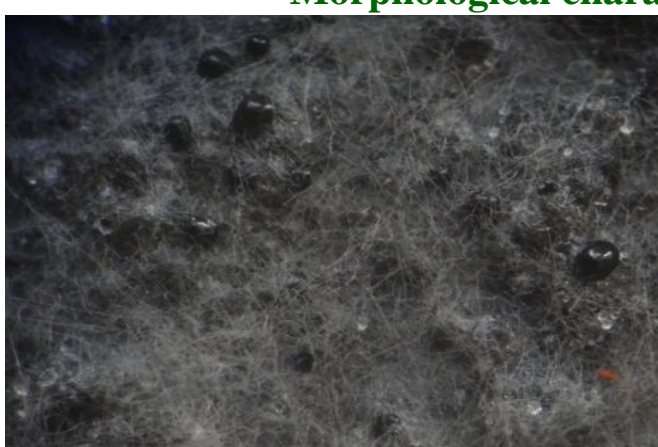

(a) Pycnidia

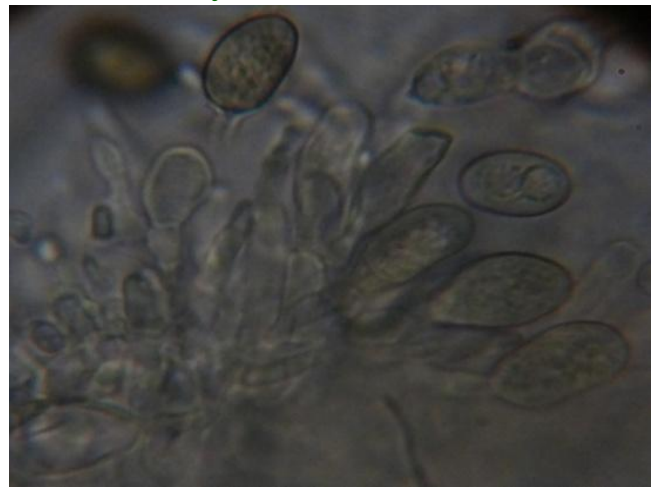

(C) Immature conidia on conidiogenous Cells (400X with optical zoom 3.2)

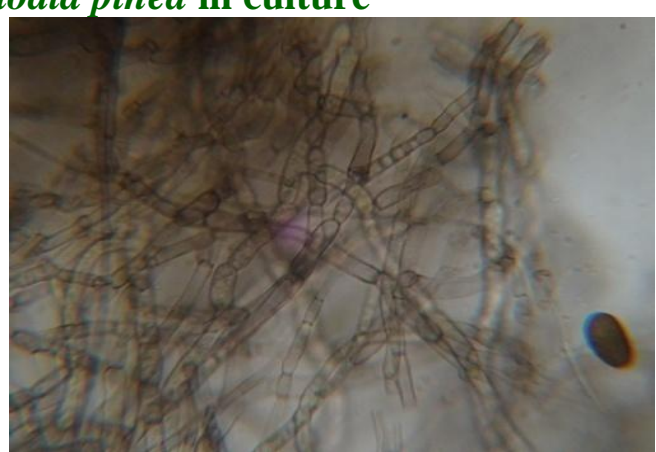

(b) Branched mycelium (400X)

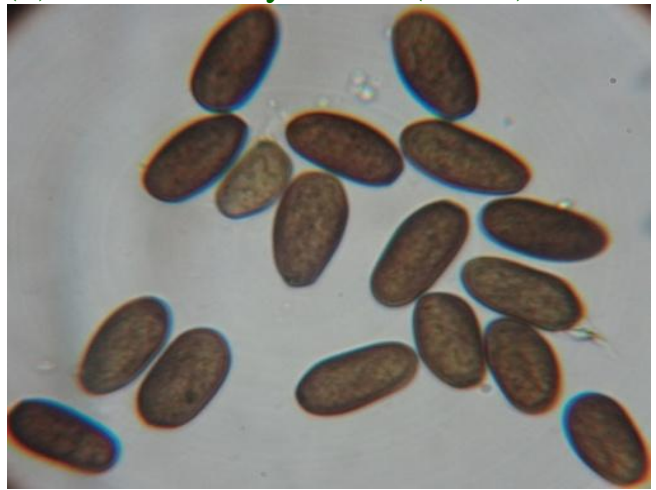

(d) Mature conidia (400X) 
The pathogen previously has also been reported from Africa, North America, Europe, Australia and New Zealand, in central North Island of New Zealand on young radiata pine (Minko and Mark, 1973; Chou, 1974), from south Africa on P. elliottii and P. taeda trees (Wingfield and Knox-Davies, 1980,) from Netherlands in 1982 (Dam et al., 1984) and again in 1985 (Kam and Van Dam, 1987) on Pinus nigra and $P$. sylvestris, from Black Hills of South Dakota on ponderosa pine (Johnson et al.,1985), from north-central United States on $P$. resinosa seedlings (Palmer et al., 1986), from USA Peterson (1977), on both pine plantation and nurseries, from South Africa on pine plantation (Zwolinski et al., 1990), from United States in 1976 on Pinus resinosa (Nicholls and Ostry, 1990), from England on nursery seedlings and South Africa on pine trees (Swart and Wingfield, 1991), from Israel on Aleppo pine (Madar et al., 1996), from NW Tunisia in the region of Djebel Khroufa near Tabarka, and in the reserve of Aïn Zena near Aïn Draham, respectively on $P$. pinaster and $P$. radiata (Linaldeddu et al.,2008), from Alabama, Louisiana, and Mississippi on Loblolly pine (Pinus taeda) (Stanosz et al., 2009). Perusal of literature reveals that there is no report of D. pinea from Pinus wallichiana though the fungus has been reported on other Pine species. Thus this forms the first report of Diplodia pinea on Pinus wallichiana from Asia.

The disease symptoms observed in the present study are more or less in agreement with Peterson and Nicholls (2004) who while working on red pine reported yellowing and browning, curling of shoots and dieback symptoms as a result of Diplodia pinea infection in nursery seedlings. Palmer and Nicholls (1985) have opined that Sphaeropsis sapinea (syn. D. pinea) is responsible for curling, stunting and death of blighted shoots of Pinus resinosa in early June in forest nurseries which is in conformity with our observations. Further, they found that the pycnidia containing mature spores were abundant on dead shoots and needles of Pinus resinosa as early as June.

Our observations are in agreement with Linaldeddu et al., (2008) who reported that the symptomatic twigs of both $P$. pinaster and $P$. radiata produced erumpent black pycnidia of $D$. pinea with dark brown conidia, oblong to clavate, aseptate, rarely one-septate, 28.9(32.7)-39.1×10.1-(11.8)-15.1 $\mu \mathrm{m}$. Peterson (1981) has also opined that the spores are transparent at first and then become brown mostly one-septate, however, $D$. pinea pycnidia may yield many spores without any cross walls (septa). Peterson and Nicholls (2004) reported that the spores of Diplodia pinea produced in pycnidia were brown at maturity, ellipsoid, usually one-celled, and about 30-45 x 10-15 $\mu \mathrm{m}$ in size. However, our reports about spore size are slightly variable from Johnson et al., (1985) who reported that, though statistically insignificant, the average length and width of spores of Diplodia pinea was $28.5 \times 12.5 \mu \mathrm{m}$ for the Black Hills isolates and $29.4 \times 12.7 \mu \mathrm{m}$ for the other isolates from Nebraska, Oklahama and Chile. Palmer and Nicholls (1983) reported that the spores were brown, sometimes one septate, rough walled and elliptical in shape ranging from 22.5-44.0 $x$ 9.5-18.5 $\mu \mathrm{m}$ in size. In our study, the fungus grew fast on PDA, produced mature black pycnidia after 21 days of incubation and required alternate light/dark periods of 12 hours. Our findings are in agreement with Brookhauser and Peterson (1971) who observed pycnidia formation when cultures were incubated at $28^{\circ} \mathrm{C}$ under 15-w florescent bulbs.

Diplodia pinea produced initial visible symptoms on $5^{\text {th }}$ and $7^{\text {th }}$ day, respectively on injured and uninjured saplings after inoculation of two year old blue pine saplings. 
These observations are supported by Brookhauser and Peterson (1971) who reported that the initial chlorotic needle blight symptoms on $P$. nigra, $P$. sylvestris and $P$. ponderosa develop more slowly on shoots inoculated in field (2-3 weeks) than on shoots inoculated in greenhouse (4-6 days). Chou (1976 a,b) found that the seedlings of Pinus radiata inoculated with $D$. pinea produced lesions after 5-6 days of inoculation and develop dieback symptoms in 2-4 weeks.

In the light of the present investigation, it is concluded that needle blight disease poses a serious threat to Blue pine and prevails in all the nurseries and pine plantations of Kashmir valley in moderate to severe form. Needle blight disease appears to be caused by a number of pathogens among which Diplodia pinea is the most frequently isolated from all the locations surveyed.

\section{References}

Ahanger, F.A., Dar, G. H., Beig, M. A. and Sofi, T. A. 2011. First report of needle blight of Blue pine (Pinus wallichiana) and Aleppo pine ( $P$. halepensis) caused by Lophodermium macci from Asia. Plant Pathology Journal 10: 181-186.

Alves, A., Correia, A. and Phillips, A.J.L. 2006. Multi-gene genealogies and morphological data support Diplodia cupressi sp. nov., previously recognized as $D$. pinea f. sp. cupressi, as a distinct species. Fungal Diversity 23: 1-15.

Available:http://spfnic.fs.fed.us/exfor/data/pes treports.cfm?pestidval $=91 \&$ langdisplay =english. Referenced: September 27, 2005.

Brookhauser, L.W. and Peterson, G.W. 1971. Infection of Austrian, Scots and Ponderosa pines by Diplodia pinea. Phytopathology 61: 409-414.

Brown, A., Rose, D. and Webber, J. 2003. Red Band Needle blight of Pine. An information note. Forestry Commission, Edinburgh, England.

Chou.1974. Pathogenicity of Diplodia pinea. Australian Plant Pathology Society Newsletter, 1 (3) p-3.

Chou, C.K.S. 1976a. Shoot dieback in Pinus radiata caused by Diplodia pinea i. Symptoms, disease development, and isolation of pathogen. NewZealand Journal of Forest Science.6: 72-79

Chou, C.K.S. 1976b. A shoot dieback in Pinus radiata caused by Diplodia pinea ii. Inoculation studies. NewZealand Journal of Forest Science.6: 409-420

Dam B.C. van and de Kam.1984. Sphaeropsis sapinea (Diplodia pinea), oorzaak van het afsterven van eindscheuten bij pinus in Nederland. Nederlandsch Boschbouw Tijdschrift.56:173-177.

Douce, G.K., Moorhead, D.J., and Bargeron, C.T. 2002. Forest Pest Control. Special Bulletin 16. College of Agricultural and Environmental Sciences, The University of Georgia, USA

Gadgil, P.D. 1984. Dothistroma Needle Blight. Forest Pathology in New Zealand, No. 5. New Zealand Forest Service, Roturua, New Zealand.

Ivory, M.H. 1994. Records of foliage pathogens of Pinus species in tropical countries. Plant Pathology 43: 511-518.

Jerry, W.R. and Richard, S.S. 2008. Nursery Diseases of Western Conifers. Forest insect and disease leaflet. NO.157. US Department of Agriculture Forest Service, USA.

Johnson, D.W., Peterson, G.W., and Dorset, R.D. 1985. Diplodia tip blight of ponderosa pine in the Black Hills of South Dakota. Plant Disease 69: 136137.

Kam, M. de and van Dam, B C. 1987. Scheutserfte en bastnecrose, veroorzaakt door Sphaeropsis sapinea in Nederland. Ned Boschbouw. Tijdschr. 59:215-219. 
Lazzizera, C.C., Frisullo, S., Alves, A., Lopes, J. and Phillips, A. J. L. 2008. Phylogeny and morphology of Diplodia species on olives in southern Italy and description of Diplodia olivarum sp. nov. Fungal Diversity, 31: 63-71.

Linaldeddu, B.T., Hasnaoui, F and Franceschini, A.2008. First report of shoot blight and dieback caused by Diplodia pinea on Pinus pinaster and $P$. radiata trees in Tunisia. Phytopathologia Mediterranea. 47(3) December: 259-261.

Madar, Z. Kimchi, M and Solel, Z. 1996. First report of Sphaeropsis sapinea on Aleppo pine in Israel. Plant Disease 80: 343.

Marks, G. C. and Minko, G. 1969. The pathogenicity of Diplodia pinea to Pinus radiata D. Don. Aust. J. Bot.17:112

Minko, G. and Marks, G.C. 1973. Drought index and the sensitivity of Pinus radiata to Diplodia pinea infection. Res.Act.72. Victoria, Australia For.Comm.47 pp

Nicholls, T.H. and Ostry, M.E. 1990. Sphaeropsis sapinea on stressed red and jack Pines in Minnesota and Wisconsin. Plant Disease 74:54-56

Palmer, M. A. 1991. Isolate types of Sphaeropsis sapinea associated with main stem cankers and top-kill of Pinus resinosa in Minnesota and Wisconsin. Plant Dis. 75:507- 510

Palmer, M. A. and Nicholls, T.H. 1983. How to identify and control Diplodia shoot blight, collar rot and cankers of conifers. North Central Research Center, USDA, Washington, USA.

Palmer, M. A., Stewart, E.L. and Wingfield, M.J. 1987. Variation among isolates of Sphaeropsis sapinea in the North Central United States. Phytopathology 77: 944-948.
Palmer, M.A. and Nicholls, T.H. 1985. Shoot blight and collar rot of Pinus resinosa caused by Sphaeropsis sapinea in forest tree nurseries. Plant Disease, 69: 739740

Palmer, M.A., Nicholls, T.H. and Croghan, C. F.1986. Fungicidal control of shoot blight caused by Sphaeropsis sapinea on red pine nursery seedlings. Plant Disease.70:194-196

Peterson, G.W. 1977. Infection, epidemiology and control of Diplodia blight of Austrian, Ponderosa and Scots pines. Phytopathology 67: 511-514.

Peterson, G.W. 1981. Diplodia pinea of pines. Forest Insects and Diseases Leaflet 161. USDA Forest Services. Washington, USA.p. 7.

Peterson, G.W. and Nicholls, T.H. 2004. Diplodia pinea. In: Forest Pests: Insects, Diseases \& Other Damage Agents. October 18, 2004 www.forestpests.org version 2.0, XHTML 1.1, CSS, 508.

Phillips, A., Alves, A., Correia, A. and Luque, J. 2005. Two new species of Botryosphaeria with brown 1- septate ascospores and Dothiorella anamorphs. Mycologia, 97:513-529.

Phillips, A.J.L., Alves, A., Abdollahzadeh, J., Slippers, B., Wingfield, M. J., Groenewald, J. Z. and Crous, P.W. 2013. The Botryosphaeriaceae: Genera and species known from culture. Studies in Mycology, 76: 51-167.

Punithalingam, E and Waterson, J. M. 1970. Diplodia pinea. Description of pathogenic Fungi and Bacteria 273.Issued by Commonwealth Mycological Institute. The Eastern Press Ltd., London.

Reddy, M.A.R. and Pandey, P.C. 1973. Cercospora needle blight of radiata pine in India. Indian Forester 99: 308-309.

Rees, A.A. and Webber, J.F. 1987. Pathogenicity of S. Sapinea on seed, 
seedling and sapling of some centralamerican Pines. Trans.Br.Mycol. Soc. 91: 273-277.

Stanosz, G.R., Smith, D.R., Fraedrich, S.W., Baird, R.E. and Mangini, A. 2009. Diplodia pinea, the cause of Diplodia blight of pines, confirmed in Alabama, Louisiana, and Mississippi. Plant Disease 93 (2): 198.

Sujan Singh., Khan, S.N. and Misra, B.M. 2007. Cercoseptoria needle blight of pines in nurseries: Disease spread and control strategies. European Journal of Forest Pathology 18: 397-400.

Swart W. J. and Wingfield M. J. 1991. Biology and control of Sphaeropsis sapinea on Pinus species in South Africa. Plant Dis 75:761-766.

USDA Forest Service. 2005. Exotic Forest Pest Information System for North America: Sphaeropsis sapinea. (Online). January 2005.

Wingfield, M. J., and Knox-Davies, P. S.1980. Association of Diplodia pinea with a root disease of pines in South Africa. Plant Dis. 64:221-223.

Zwolinski, J. B., Swart, W. J., and Wingfield, M. J. 1990. Economic impact of a posthail outbreak of dieback induced by Sphaeropsis sapinea. Eur.J. For.Pathol. 20: 405-411

\section{How to cite this article:}

Shubana Bhat, Muzafer A. Beig, G. H. Dar, Shanaz Yousuf, Farahanaz Rasool and Vikas Gupta. 2018. First Report of Diplodia pinea [(Desmaz.) J. Kick x fil] on Blue pine (Pinus wallichiana Jackson) from Asia. Int.J.Curr.Microbiol.App.Sci. 7(06): 3158-3166.

doi: https://doi.org/10.20546/ijcmas.2018.706.371 